\title{
Teaching NeuroImages: CNS hemangioblastomas in von Hippel-Lindau disease with exon 3 deletion
}

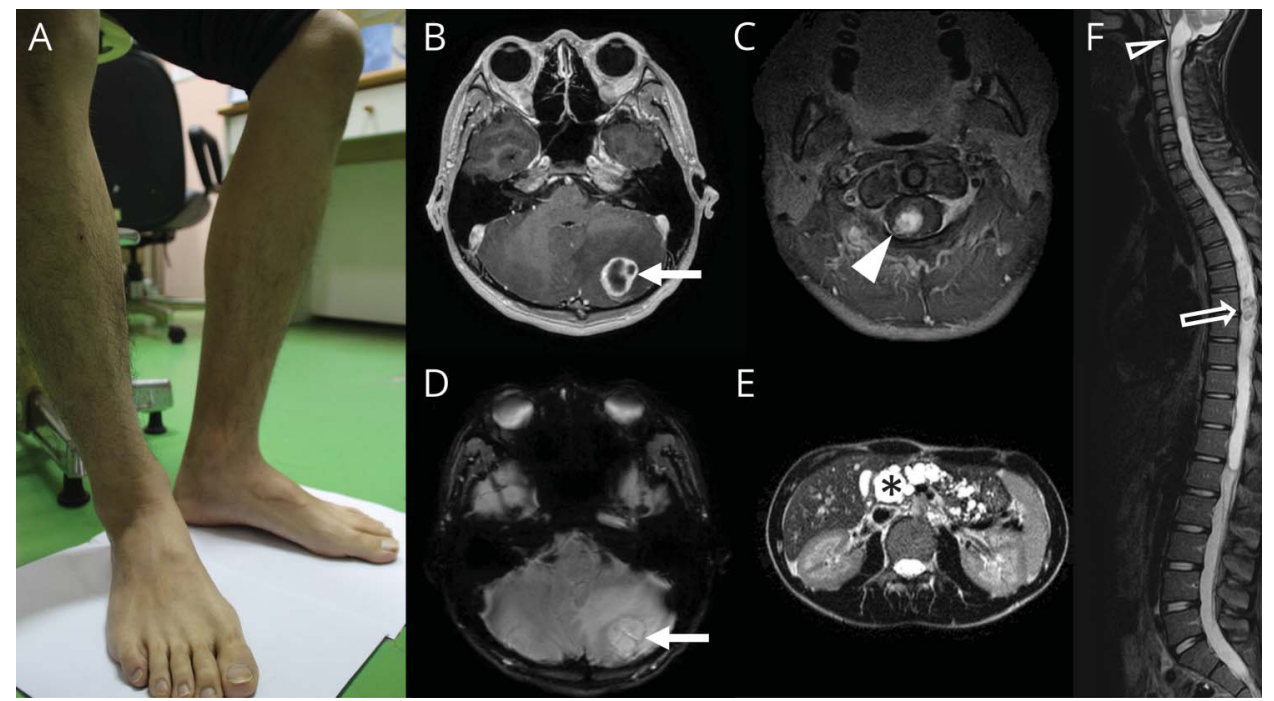

(A) Calf atrophy. (B, C) Hemangioblastomas at left cerebellum (arrow) and cervicomedullary junction (arrowhead) (enhanced T1-weighted images). (D) Feeding artery (arrow) (gradient echo image). (E) Multiple pancreatic cysts (asterisk) (T2weighted image). (F) Another hemangioblastoma at T7-8 (open arrow), syringobulbia (open arrowhead), and thoracic syringomyelia (T2-weighted image).
A 14-year-old boy developed progressive bilateral leg weakness for 5 months. Physical examinations showed calf muscle atrophy (figure, A) and hyperreflexia. Spinal lesion of slow progression was suspected.

Spine and brain MRI showed hemangioblastomas at spinal cord and cerebellum, syringobulbia, and thoracic syringomyelia (figure, B-D and F). Abdominal MRI revealed multiple pancreatic cysts (figure, E). The patient also had retinal hemangioblastomas. Genetic analysis showed heterozygous de novo exon 3 deletion of VHL gene.

Weakness occurs in $65 \%$ of von Hippel-Lindau disease cases. ${ }^{1}$ Our patient had truncating mutation, correlating to a higher rate of hemangioblastoma, but a lower risk for pheochromocytoma. ${ }^{2}$

\section{Author contributions}

Drs. Chen and Tsai participated in the neuroimaging interpretations and clinical care of the patient. The manuscript was drafted by Drs. Chao and Tsai and was revised by Dr. Chen.

\section{MORE ONLINE}

$\rightarrow$ Teaching slides

links.lww.com/WNL/A621

From the Departments of Diagnostic Radiology (C.-C.C., Y.-S.T.) and Pediatrics (L.-W.C.), National Cheng Kung University Hospital, College of Medicine, National Cheng Kung University, Tainan, Taiwan.

Go to Neurology.org/N for full disclosures. Funding information and disclosures deemed relevant by the authors, if any, are provided at the end of the article. 


\section{Study funding}

No targeted funding reported.

\section{Disclosure}

The authors report no disclosures relevant to the manuscript. Go to Neurology.org/N for full disclosures.

\section{References}

1. Dornbos D III, Kim HJ, Butman JA, Lonser RR. Review of the neurological implications of von Hippel-Lindau disease. JAMA Neurol Epub 2018 Jan 29.

2. Frantzen C, Klasson TD, Links TP, Giles RH. von Hippel-Lindau syndrome. In: GeneReviews [online]. Seattle: University of Washington; 1993-2018. Available at: ncbi.nlm.nih.gov/books/NBK1463/. Accessed March 23, 2018. 


\section{Neurology}

\section{Teaching NeuroImages: CNS hemangioblastomas in von Hippel-Lindau disease with exon 3 deletion}

Cheng-Chen Chao, Yi-Shan Tsai and Li-Wen Chen

Neurology 2018;91;e601-e602

DOI 10.1212/WNL.0000000000005957

This information is current as of August 6, 2018

Updated Information \& Services

Subspecialty Collections

Permissions \& Licensing

Reprints including high resolution figures, can be found at: http://n.neurology.org/content/91/6/e601.full

This article, along with others on similar topics, appears in the following collection(s):

All Pediatric

http://n.neurology.org/cgi/collection/all_pediatric

MRI

http://n.neurology.org/cgi/collection/mri

Other neurocutaneous disorders

http://n.neurology.org/cgi/collection/other_neurocutaneous_disorders Spinal cord tumor

http://n.neurology.org/cgi/collection/spinal_cord_tumor

Information about reproducing this article in parts (figures,tables) or in its entirety can be found online at:

http://www.neurology.org/about/about_the_journal\#permissions

Information about ordering reprints can be found online:

http://n.neurology.org/subscribers/advertise

Neurology ${ }^{\circledR}$ is the official journal of the American Academy of Neurology. Published continuously since 1951 , it is now a weekly with 48 issues per year. Copyright @ 2018 American Academy of Neurology. All rights reserved. Print ISSN: 0028-3878. Online ISSN: 1526-632X.

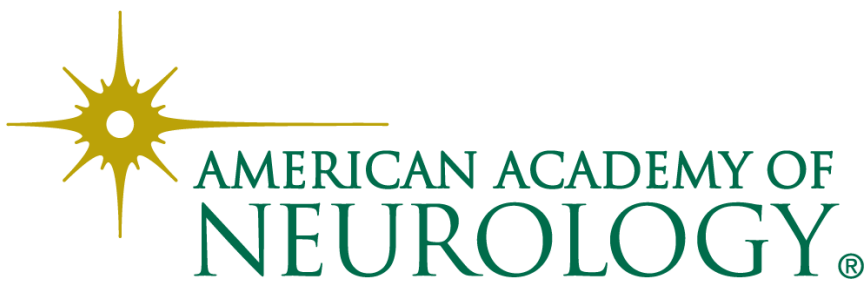

